$\xi=-1$

\title{
Review of the Issues and Governance of Genetically Modified Organism in Malaysia
}

\author{
Mohamad Hafis Aliaziz ${ }^{1}$, Suhaimi Ab Rahman ${ }^{2} *$ \\ ${ }^{1}$ Halal Product Research Institute, Universiti Putra Malaysia \\ ${ }^{2}$ Faculty of Economics and Management, Universiti Putra Malaysia \\ *Corresponding author E-mail: suhaimiabrahman@upm.edu.my
}

\begin{abstract}
This paper discusses the issues of modern practice of biotechnology in Malaysia. As a developing country, Malaysia is putting a lot of effort on the development of biotechnology which is targeted to be a new economic engine for the country. Although the modern biotechnology with the focus in producing genetically modified products seems to give many benefits, but it has raised concerns on several issues arising out of the use of the modified organisms. Thus, a good governance of GMO is required to control the issues so that it can reduce the concerns over safety and halal issues. It is suggested that although the government has introduced laws that govern the practice of biotechnology, it still requires improvement so it can provide overall control to the practice of modern biotechnology in Malaysia.
\end{abstract}

Keywords: Genetically Modified Organism, Biotechnology

\section{Introduction}

\subsection{Genetically Modified Organism and its Principles}

Biotechnology is a science that combines the technology and biology together in order to modify an organism or product of an organism in order to produce a better product for the use of humankind. According to United Nations, biotechnology is defined as any technological application that uses biological systems, living organisms, or derivatives thereof, to make or modify products or processes for specific use. Biotechnology is also defined as the application of biological processes to the production of materials of use especially in medicine and industry [1]. Genetic engineering is the main stream of biotechnology which produces genetically modified organism (GMO) such as pest resistance crops, increase antioxidants and micronutrients of fruits [2] and also to develop pharmaceuticals products such as vaccine [3]

Application of biotechnology has started since 4000 BC during the process of alcohol and bakeries production by Egyptians through fermentation process [4]. As the time goes by, the technology becomes more sophisticated and many new discoveries done by scientists in biology field thus come out with the idea of modern biotechnology [5]. Modern biotechnology is involving the application of cellular, molecular and genetic processes in production of goods and services involving high technology tools and machines such as Polymerase Chain Reaction, gene gun, electrophoresis and complex material such as recombinant DNA, cell fusion and engineered protein [6] to produce GMO. Scientist believed that the modern biotechnology is becoming the backbone of the biotechnology field in future as the field is too wide to explore [7].

Modern biotechnology basically deals with the deoxyribonucleic acid (DNA) of an organism after the discovery of the information regarding the DNA by Watson and Crick in 1953 (Organisation for Economic Co-operation and Development (OECD) [8]; Mar- zukhi and Umi Kalsom [9]. Specific tools are used to modify the genetics of organism [10] thus altering the protein to make changes on the characteristics of the organism itself [11]. The modification that is done through genetic engineering usually does not occur in natural way either by mating or natural recombination [12].

Basically, genetically modified organism is developed to improve human life with advantages such as improving crops, health and industrial sectors [11]. However, to make the way clearer, researchers have put some basic guideline on the development of the GMO that is beneficial to human, do not cause risk to human and environment and to promote justice and fairness to people [13]. Another group of researcher says that the modern biotechnology cannot be separated with the social and ethics theories such as rights theory, theories of justice, consequentialism and utilitarianism, precautionary principle, environmental ethics and religion [14]. In conclusion, the research and development of the modern biotechnology is to give good impact to human life with all the benefits promised by the technology without causing any bad effect to them from any aspect of life.

Genetically modified organisms do have a lot of advantages over normal species in the aspect of physical and products. Through modern biotechnology, scientists are able to produce genetically modified food, crops and animal which is very beneficial to people [15].

In agriculture sectors, development of transgenic crops and animal such as livestock, poultry and fish has helped farmers a lot in term of quality and production of food [16]. Transgenic crops have been used to helped farmers overcome the problem of pest and insect without depending on pesticide and insecticide anymore [17] thus reduce bad side effects of those hazardous materials to human [18]. Besides that GM crops also have better resistance towards extreme condition [11] and produce higher yield and more nutrients $[12,19]$. This has been practiced in India and it showed an increasing of $80 \%$ of cotton whenever the farmers use GM cotton instead of normal one [20]. Therefore, the contribution 
of modern biotechnology in the field of agriculture is very helpful in developing the field and also other field.

Nowadays, genetically modified organism is practiced all over the world mainly in agriculture and food. According to Prakash [21], biotechnology has helped some countries mainly in Africa to develop their agriculture sectors and feed their citizens. The product is marketed both in local and international market. Netto [22] reported that around $21 \%$ of the raw food in Malaysian local market is derived from GMO especially raw beans and tofu. This happens because most of the food products are imported from foreign countries like Thailand and Vietnam.

In addition, research in medical sectors also intensively done by scientists to look for chances to improve through modern biotechnology. It is reported that the practice of medicine has been revolutionized through modern biotechnology [23]. Recombinant DNA techniques, monoclonal antibody technology and high technology instrument play very important role to improve the medical field [24]. Researchers do apply modified organism in research regarding the development of new pharmaceuticals drugs, antibody and gene therapy and also to improve the original ones [1].

\section{Issues Regarding Genetically Modified Or- ganism}

Even though GMO is promising to benefit people, yet it has been worrying people with some issues. According to World Health Organization (WHO) most of the issue discussed is regarding the safety of the product, effect on the environment, religious and ethical issues. Many discussions and debates have been organized around the world to look for the best way to practice the technology [25].

The awareness on the product of GMO has started to be taken seriously by Malaysian citizens. A survey on the awareness of Malaysians on the GMO product showed that the awareness level is increasing among them [26].

The controversy on GMO begins to attract people's attention since a long time ago especially after the issue of the population of monarch butterfly in New York is affected by genetically modified corn $[27,28]$. Even though the GM corn is not modified to give bad impact on the butterfly, but the side effect of the product has poisoned the larvae of the butterfly thus reduced its population [28]. Since then, the issues of GMO begin to become a very controversial among people especially in Europe [29].

Besides the matter of safety, religious matter also becomes a big issue especially for Muslim. There are some reports saying that the GMO products do contain non-permissible elements like pig gene and gene of un-slaughtered animal [30, 31]. Human haemoglobin, milk containing human coagulation factor and human-pig organ are some of the GM products that applying non-permissible elements that might be consumed by Muslims no well monitoring is taken onto the products [32].

According to National Council of Fatwa Islamic Affairs Malaysia the genetically modified food containing forbidden elements like pig DNA and un-slaughtered animal are not allowed to be consumed by Muslim consumers. Even though the forbidden elements used are very little, but according to 'usul fiqh' method, "Origin of the things to be lawful, and the original ruling of an illegal is illegal ruling. When mixed with an illegal halal with either many or few, then the ruling is illegal", it is still considered as 'haram [33]. Besides that, the use of substances that hazardous to human health and environment also prohibited [34].

Responding to the controversy, many parties have delivered their worries towards the practice of GMO. For instance, Organization for Economic Cooperation and Development (OECD) was developed a tool for the assessment of the GMF in order to confirm about the safety of new proteins, occurrence and implication of unintended effects and allergenicity of new proteins [35]. Countries involved in the GMO has also taken an approach to ensuring the GMO products are safe to use by implementing a security system based on Cartagena protocol [36].

\section{Governance of Genetically Modified Organ- ism in Malaysia}

Nowadays, biotechnology sector is becoming an important agenda to be focused by Malaysian government due to its potential to become a new economic engine for the country [37]. Ministry of Science, Technology and Innovation has allocated a lot of funds to improve the biotechnology sector in Malaysia, especially in the research and development (R\&D) in the field of agriculture, healthcare and industrial biotechnology which most of the activities are involving the genetic modification of organisms [38].

Previously, Malaysian government had given approval to import GMO products from other countries and market them in local market [39]. The GMO products that have been imported are Roundup Ready soybean, MON 810 maize, MON 863 maize and NK 603 [40]. But now, Malaysia is already developing GMO like animal recombinant vaccines [41] and biodegradable plastic in transgenic oil palm [42]. Consumer Association of Penang also reported that the GM food is now widely sold in the local market since few years ago [43].

Thus, the modern biotechnology is seemed to be a potential field to be developed by the government as it promises benefits that can improve human life and contributes to the economic growth of the country.

In regulating GMO, Malaysian government has enforced Biosafety Act 2007 to regulate the release, importation, exportation and contained use of living modified organisms, and the release of products of such organisms, with the objectives of protecting human, plant and animal health, the environment and biological diversity, and where there are threats of irreversible damage, lack of full scientific evidence may not be used as a reason not to take action to prevent such damage and to provide for matters connected therewith [44].

This matter is relevant with the initiative outlined in the National Biotechnology Policy as one of the main thrusts is to have a legislative and regulatory framework development [38]. This Act has been enforced since 2009 but regulation that provides the detail risk assessment is not yet released [45, 46]. International Centre for Trade and Sustainable Development (ICTSD) reported that the Act is not fully enforced within the industrial sectors due to some problem at the early stage of the implementation phases [47].

In addition, there has not yet any systematic law and policy implemented as a guideline that parallel to halal requirements provided for Muslim in practicing and consuming GMO [39, 48]. Unlike in Europe, Malaysian government yet to put much emphasize on the governance and control of the product. The product is free to enter the market without any labeling since there is no legislation on that [49]. Therefore, consumers are not well informed whether the product that is available in the market is actually a genetically modified product.

Many conferences and discussions were conducted among 'Ula$m a$ ' (Muslim scholars) and scientist on this debatable issue. Most of the discussions emphasize on the status of GMO in the aspect of 'halal' and 'haram'. However, the status of 'halal' or 'haram' still in infancy stage especially in Malaysian community [50]. Some studies have been done on the Islamic perspective of the GMO like 'Islam and Biotechnology' in 2005 which highlighted the Islamic principles in legitimizing of research and development regarding biotechnology [51]. An intensive study also has been conducted on the method in determining the 'halal' and 'haram' status according to ' $u$ sul fiqh' method [46]. The GMO however must be Shariah compliant to be consumed by Muslim especially in Malaysia.

Since industry involving GMO is very common in the world and the product is globally marketed, study on the issue should be continuously done especially by Muslim scholar in order to ensure 
that the product used by Muslim is free from any 'haram' elements.

In Malaysia, the government has developed Malaysian Halal Standards to generalize the practice of 'halal' in the country. According to Ministry of International Trade and Industry (MITI) [52], there are already five Standards that have been published by Standards Malaysia as related to 'halal' as June 2010. The Standards are MS 1500:2009 (E), Halal Food - Production, Preparation, Handling and Storage - General Guidelines (Second Revision), MS 2200:Part 1:2008, Islamic Consumer Goods - Part 1: Cosmetic and Personal Care - General Guidelines, MS 2400-1:2010, Halalan-Toyyiban Assurance Pipeline - Management system requirements for transportation of goods and/or cargo chain services, MS 2400-2:2010, Halalan-Toyyiban Assurance Pipeline - Management system requirements for warehousing and related activities and MS 2400-3:2010, Halalan-Toyyiban Assurance Pipeline Management system requirements for retailing.

One of the aspects that have to be fulfilled by a product in order to make it 'halal' is complying with 'syariah' law. Complying with 'syariah' means the product must be following the 'syariah' standards that have been set by the authorities like Department of Islamic Development Malaysia (JAKIM) and Ministry of Domestic Trade, Co-operatives and Consumerism (KPDNKK).

\section{Conclusion}

Production of GMO seems to benefits human in many aspects of life. However, there are some issues arise regarding the safety, ethics and religious matter. To overcome this problem, the government has put some efforts to govern and control the activity regarding the GMO to reduce the effects. Commitment from government of Malaysia to establish a good governance on the GMO through gazetting the Biosafety Act 2007 is a good effort in regulating the organisms and its' product. However, there is still many improvement required in order to promise a comprehensive protection to human, animal, plant and environment. Besides that, element of 'halalan thoyyiban' should be included for the protection of Islamic consumers. Previous studies show that there is urgency in developing the Shariah compliance governance of GMO in Malaysia to ensure that Muslim consumers are well protected from non 'halal' source. Even though the Biosafety Act 2007 [53] does contain several elements that suit with the Shariah, however, the main matters that should be addressed are not included in the act. With the incorporation of Shariah elements in the governance of GMO in Malaysia, it will give comprehensive protection towards both Muslim and non-Muslim consumers to the GMO products besides protecting animal and environment. However, there are still gaps of the studies which should be narrowed down. In conclusion, further investigation and study are required to improve the governance of GMO in Malaysia.

\section{References}

[1] Rastogi SC (2007), Biotechnology Principles and Application. Alpha Science International Ltd. U.K.

[2] Lemaux PG (2006), Introduction to genetic modification. Agricultural biotechnology in California series, 8178

[3] Houdebine L-M (2009), Production of pharmaceutical proteins by transgenic animals. Comparative immunology, microbiology and infectious diseases 32, 107-121.

[4] Fiechter A \& Bayeler W (2000), History of biotechnology, volume 1. Springer-Verlag. pp. 1. GRAIN (2004).GM cotton set to invade West Africa: Time to act! Retrieved from http://www.grain.org/briefings/?id=184

[5] Robert B (1989), Janus-faced biotechnology: an historical perspective. Trends in Biotechnology 7(9), 230-233.

[6] Zika E, Papetryfon I, Wolf O, Gomez-Barbero M, Stein AJ \& Bock A-K (2007), Consequences, Opportunities and Challenges of Modern Biotechnology for Europe. Office for Official Publications of the European Communities.
[7] Henk vdB (2009), Philosophy of Biotechnology. In M Anthonie (Ed.), Philosophy of Technology and Engineering Sciences 13011340, Amsterdam: North-Holland.

[8] Organisation for Economic Co-operation and Development (OECD) (1999), Policy Brief: Modern biotechnology and OECD.

[9] Marzukhi H \& Umi Kalsom AB (2005), Pengenalan kepada bioteknologi pemakanan dan pertanian. In Syaikh Mohd Saifuddeen SMS, Wan Roslili,AM \& Azrina S (Eds), Sempadan bioteknologi menurut Islam. Institut Kefahaman Islam Malaysia (IKIM), 21-31.

[10] Backman K (2001), The advent of genetic engineering. Trends Biochem Sci 26(4), 268-270.

[11] Keener K, Hoban T \& Balasubramanian R (2012), Biotechnology and its application. Department of food science. The North Carolina Cooperative Extension Service. North Carolina State University. Retrieved http://www.ces.ncsu.edu/depts/foodsci/ext/pubs/bioapp.html

[12] Lin D (2011), Arguments For and against genetically modified organisms: GMOs from an animal rights and vegan perspective. Retrieved from http://animalrights.about.com/od/animalsusedforfood/a/ArgumentsFor-And-Against Genetically-Modified-Organisms_2.htm

[13] Christensen R, Davis J, Ochoa GMP \& Schmit W (2002), Biotechnology: An Overview. European Investment Bank.

[14] Latifah A \& Jamaluddin MJ (2004), Ethical aspects of genetically modified organisms released into environment. Malaysian Journal of Environmental Management 5, 99 - 111.

[15] Hulse JH (2004), Biotechnologies: Past history, present state and future prospects. Trends in Food Science \& Technology 15, 3-18.

[16] United Nations Environment Programme (2006), Africa environment outlook 2: Our environment, our wealth. United Nations Environment Programme.

[17] Kaskey J (2009),. Monsanto, dow chemical win approval for modified corn (Update3). Retrieved from http://www.bloomberg.com/news/

Bolognesi C, Merlo FD (2011), Pesticides: Human Health Effects, In: Editor-in-Chief: Jerome O. Nriagu, Editor(s)-in-Chief, Encyclopedia of Environmental Health, Elsevier, Burlington 438-453.

[18] James C (2003) Global review of commercialized transgenic crops. Current science 84 (3).

[19] Qaim M \& Zilberman D (2003). Yield effects of genetically modified crops in developing countries. Science, 299, 900.

[20] Prakash CS (2011), Benefits of biotechnology for developing countries. Retrieved from http://www.agbioworld.org/biotechinfo/topics/dev-world/benefits.html

[21] Netto (2007), Malaysia to enforce labeling of GM foods. In the news about GM issues of gm-free Ireland. Retrieved from http://www.gmfreeireland.org/news/2007/apr.php

[22] Márcio AF \& Belem (1999), Application of biotechnology in the product development of nutraceuticals in Canada. Trends in Food Science \&amp; Technology 10(3), 101-106.

[23] Hood L, Biotechnology and Medicine of the Future. JAMA 259(12), 1837-1844.

[24] Rigaud N (2008), Biotechnology: Ethical and social debates. In the OECD International Futures Project on "The Bioeconomy to 2030: Designing a Policy Agenda".

[25] Latifah A, Noor Ayuni AA, Mohd Fadhli H, Abdul Latif S \& Mohamad Sabri H (2011), Awareness and knowledge on modern biotechnology. African Journal of Biotechnology 10(58), $12448-12456$.

[26] Losey JE, Rayor LS \& Carter ME (1999), Transgenic pollen harms monarch larvae. Nature, 399.

[27] Hellmich RL, Siegfried BD, Sears MK, Stanley-Horn DE, Mattila HR, Spencer T, Bidne KG, Daniels MJ \& Lewis LC (2001), Monarch larvae sensitivity to Bacillus thuringiensis purified proteins and pollen. Proc. Natl. Acad. Sci. USA 98:11925 11930.

[28] Briggs H (2001), The biotech debate: The monarch butterfly. In the BBC News. Retrieved from http://news.bbc.co.uk/2/hi/science/nature/1298397.stm

[29] Hazzah K (2000), Are GMO's Halal?. Retrieved from http://www.agbioworld.org/biotech-info/religion/halal.html

[30] Rahman LA (2009), Isu halal tiada penghujung. Alambaca Sdn. Bhd. Malaysia, 68-78.

[31] Prather RS, Shen M \& Dai Y (2008), Genetically modifed pigs for medicine and agriculture. Biotechnology and Genetic Engineering Reviews 25, 245-266.

[32] National Council of Fatwa Islamic Affairs Malaysia (JAKIM) (1999), Biotechnology in Food \& Drink. Retrieved from 
http://www.e-fatwa.gov.my/fatwa-kebangsaan/bioteknologi-dalammakanan-minuman

[33] National Council of Fatwa Islamic Affairs Malaysia (JAKIM) (2011), Eating Genetically Modified Food Law (Genetic Modified Food). Retrieved from http://www.e-fatwa.gov.my/fatwakebangsaan/hukum-memakan-makanan-terubahsuai-genetikgenetic-modified-food

[34] Kuiper HA, Kleter GA, Noteborn HPJM \& Kok EJ (2002), Substantial equivalence - An appropriate paradigm for the safety assessment of genetically modified foods? Toxicology 181-182, 427-431.

[35] Convention on Biological Diversity (CBD) (2012), The Cartagena Protocol on Biosafety. Retrieved from http://bch.cbd.int/protocol/parties/

[36] BIOTEK (2009), About us. Retrieved from http://www.biotek.gov.my/index.php?option=com_content\&view= article \&id=46\&Itemid $=5$

[37] MOSTI (2005), Biotechnology for wealth creation and social well being : The way forward, Ministry of Technology and Innovation (MOSTI), Malaysia.

[38] Consumer Association of Penang (CAP) (2009), Revoke and remove approved GM food from our shelves. Retrieved from http://www.consumer.org.my/index.php/food/safety/136 revokeand-remove-approved-gm-food-from-our-shelves

[39] International Service for the Acquisition of Agri-biotech Applications (ISAAA) (2011), Approved GM events in Malaysia | GM approvals in Malaysia. Retrieved from http://www.isaaa.org/gmapprovaldatabase/country/default.asp?Cou ntryID=120\&GMAprovalsin=Malaysia

[40] Malaysian Biotechnology Information Centre (MABIC) (2006), Biotechnology in Malaysia. Retrieved from http://www.bic.org.my/?action=localscenario\&do=biotechnology

[41] Parveez GKA, Masri MM, Zainal A, Majid NA, Yunus AMM Fadilah HH, Rasid O \& Cheah SC (2000), Transgenic oil palm: production and projection. Biochemical Society Transactions 28, 6 .

[42] Consumer Association of Penang (CAP) (2006), Halal haram. Consumer Association of Penang, Malaysia 145.

[43] Biosafety Act (2007) (Act 678).

[44] Latifah A \& Abdul Latif S (2010), Permasalahan etika dalam bioteknologi. Institut Alam dan Tamadun Melayu, Universiti Kebangsaan Malaysia 91-105.

[45] Latifah A, Ayuni AA, Mohamad Hanafi G, Jamil A, Abdul Latif S, Mohamad Sabri H \& Nik Marzuki S (2010), Ethical perception of modern biotechnology with special focus on genetically modifed food among Muslims in Malaysia. Asia-Pacifc Journal of Molecular Biology and Biotechnology 18 (3), 359-367.

[46] ICTSD (2009), Malaysian biosafety act enters into inforce. Retrieved from http://ictsd.org/i/news/biores/65569/

[47] MacKenzie V (2002), GM foods : Will their fate be decided in Asia. Report for ASrIA, the Association for Sustainable and Responsible Investment in Asia with support from Cazenove Asia, pg 16.

[48] International Service for the Acquisition of Agri-biotech Applications (ISAAA) (2006), Labelling. Retrieved from http://www.isaaa.org/kc/Publications/htm/articles/Labeling/malaysi a.htm

[49] Ismail SM (2008), Makanan ubahsuai genetik (GM Food) : Satu analisis hukum. Universiti Malaya.

[50] Safian MYH (2005), Islam and biotechnology: With special reference to genetically modified foods. Science and Religion: Global Perspectives.

[51] Ministry of International Trade and Industry (MITI). Halal Hub Retrieved from http://www.miti.gov.my/cms/content.jsp?id=com.tms.cms.section.S ection_8ab65e4b7f000010-72f772f7-ce3196c6

[52] Laws of Malaysia, Act 678 Biosafety act (2007). 